\title{
PSYCHIATRY IN THE 1870s \\ Centenary of the Mental After-Care Association
}

The Mental After-Care Association has just celebrated its centenary. An account of the meeting at which it was founded apeared in the Joumal of Mental Science for October 1879.

Sir William Ellis, of Wakefield and Hanwell, was the first to call attention to the need for some form of assistance to patients discharged from asylums. At both hospitals, in the $1820 \mathrm{~s}$ and $30 \mathrm{~s}$, he succeeded in establishing charitable funds for the purpose-the 'Harrison' fund at Wakefield and 'Queen Adelaide's' at Hanwell*. In his Treatise on Insanity, published in 1838, he wrote:

"But something further is still wanted. A comfortable place where patients might find food and shelter and a home until they could procure employment would be an invaluable blessing ... Many patients might thus be eventually restored to society who are now compelled to remain in the asylum in consequence of their retaining some erroneous view on some unimportant matter.'

Forty years later no such a home had yet come into existence. But now the need had been perceived and brought to light by a man endowed with energy and powers of persuasion, the Rev. Henry Hawkins, chaplain to Colney Hatch Asylum. He began his campaign in 1871 with an article in the Joumal on 'Convalescent Homes in Connection with Asylums', and by 1879 he had enlisted enough support both from eminent psychiatrists and from persons interested in social work to enable a meeting to be called and an Association to be formed.

Our Joumal's report appeared in the Notes and News section, but Mr Hawkins' paper was printed separately as an 'original article'. Extracts from the paper are given here in their apropriate place.

'After-Care of Convalescents'

'A Meeting was held on 5 June 1879 at the house of Dr Bucknill, 89 Wimpole St., to consider the subject of the "After-care of poor and friendless fernale convalescents on leaving asylums for the insane". There were present: Dr and Mrs Bucknill, Miss Cons, Dr Lockhart Robertson, Dr D. Hack Tuke, Dr W. G.

${ }^{*} \mathrm{He}$ was granted this Royal patronage through the intermediary of Col. Clitherow, of Boston Manor, the Chairman of the Hanwell Visiting Justices. Col. Clitherow and his sister, Mary (who later wrote her reminiscences of the Court) were on terms of friendship with King William IV and Queen Adelaide, who when Duke and Duchess of Clarence had been neighbours of theirs at Bushey Park. This also helped to get Dr Ellis his knighthood.
Marshall, Dr Harrington Tuke, Rev. H. Potter, Rev. G. H. Lee and Rev. H. Hawkins. $\dagger$

A paper was read by Rev. H. Hawkins:

\section{Extracts from Mr Hawhins' paper:}

Those whose need is direst are patients, patients without relatives or friends-deserted wives, widows, single persons in various callings ... convalescents whose actual dismissal though warranted by the state of their health is delayed, postponed from month to month because they are friendless or estranged or remote from their friends. Or the friends may be so poorly lodged as to be unable to receive them; or they may be better pleased that the convalescent should find in the asylum a permanent abode rather than become a burden to themselves. Or if the patient's official guardians, from motives of humanity, decline to expose her to disturbing penury or even worse, so that she continues still a patient, the bitterness of hope deferred may cause her to fall back into mental derangement.

For some who have relatives or friends the transition from a spacious asylum ward, with its comforts and even refinements, to some close musty room in a crowded court would be the reverse of salutary. And the only occupation that could be provided would be that of a drudge of all work-a 'slavey'.

There should be an association to carry out the objects indicated here. The authorities of asylums would in due time welcome the alliance of an association which would endeavour to provide suitable occupation. An interview would enable a judgement to be made of the work best adapted to the capacities of the individual. Benevolent persons may be found willing to receive recovered patients on moderate payment or even gratuitously.

There are cases for whom the arrangements of a well-ordered convalescent home might be better adapted. It could be an ordinary roomy comfortable house. The inmates would carry on the domestic work; they would have full liberty to inquire after employment, for which assistance would be given

†Dr Bucknill had recently retired from the position of Lord Chancellor's Visitor; Dr Lockhart Robertson still occupied that position; Dr Hack Tuke and Dr Harrington Tuke were in consulting practice; Dr Marshall was one of the two Medical Superintendents at Colney Hatch, Hawkins' own hospital; from a footnote to Hawkins' article it is clear that Marshall's colleague, Dr Edgar Sheppard, also supported the movement. Miss Cons was Emma Cons, of 'Old Vic' fame; she was later a member of the LCC Asylums Committee.

Alexander Walk 
them. Such a home might occasionally be serviceable as a haven of refuge to persons, formerly asylum patients, who were in danger of a relapse.

The mainspring of the association would be some devoted pioneer, who would gather round her a band of like-minded women among whom would be distributed various departments of service. A Council of gentlemen would supervise financial and general business.'

'At the conclusion of $\mathrm{Mr}$ Hawkins' paper an interesting discussion took place.

'It was moved by Dr Lockhart Robertson and seconded by Dr Hack Tuke that this meeting do form itself into an Association. The names of $\mathrm{Dr} \mathrm{J}$. Duckworth Williams and Dr Savage were added to those already given.

'Dr Bucknill was invited to take the office of President and the Rev. H. Hawkins was asked to be Secretary.
'The Secretary was instructed to communicate with members and others likely to take an interest in the subject and subsequently to communicate with the President with the view of calling another meeting.'

On 29 July a meeting of ladies to consider the same subject was held at 86 Portland Place by kind permission of Mrs Miller. About 15 ladies were present, and Miss Cons consented to accept temporarily the office of Secretary.'

Joumal, January 1880. 'Another meeting of the Association for assisting insane convalescents was held on the 27 November. Lord Shaftesbury has kindly consented to become the Patron. A Committee of ladies was appointed, who enter heartily into the work. The question of providing a Distinct Home was discussed. It was decided not to proceed with this at present, but to be content with endeavouring to provide temporary homes in cottages and other houses and finding suitable places for those willing to go out to service.'

\section{NEWS ITEMS}

\section{THE NEW DHSS}

In the new Government Mr Patrick Jenkin is Secretary for the Social Services; Dr Gerard Vaughan is a Minister of State and Minister of Health within the Department; and Mrs Lynda Chalker and Sir George Young are the Under-Secretaries.

Dr Gerard Vaughan is a Foundation Fellow of the College. Born in 1923, he qualified from Guy's Hospital in 1947 and took the M.R.C.P. in 1949. He trained in psychiatry at the Bethlem and Maudsley Hospitals, obtaining the Academic D.P.M. in 1953. He was elected F.R.C.P. in 1966. He holds the position of Consultant Physician to Guy's, in the specialty of child psychiatry. Until his appointment to the Ministry he was a member of the Medical Research Council.

Dr Vaughan was first elected to Parliament in 1970 , when he won the Reading constituency for the Conservatives. He has since been re-elected three times for the revised constituency of Reading South, each time with an increased majority.

Mrs Lynda Chalker has represented Wallasey since 1974. She has throughout taken a special interest in mental health matters, as shown by her questions to Ministers and contributions to debates.

Sir George Young, an economist, initiated a debate on Alcoholism towards the end of the last Parliament. A summary of this debate appears in this issue (p 118).

Dr Vaughan and Mrs Chalker took part in the recent debate on the proposed revision of the Mental Health Act; summaries of their speeches will be found on pp 79 and 80 of the May issue of the Bulletin. (It is regretted that Dr Vaughan's first name was then mistakenly printed as 'Gerald'.)

\section{LEICESTER PSYCHOTHERAPY COURSE.}

An Introductory Course in Psychotherapy was held at the Towers Hospital, Leicester during June and July 1978."

The course was organized locally by the Leicester Postgraduate Training Committee and myself, but advice on content and outside speakers was given by the Executive Committee of the Psychotherapy Section of the College. The intention was to provide an intro- duction to the range of psychotherapies, and to stimulate the interest of trainees by providing an atmosphere in which they could meet, discuss ideas and cases and identify future training needs. The Course received financial support from the Section and the Midlands Division of the College, who both donated their grant from Wyeth Laboratories to this purpose. A similar venture had been organized by $\mathrm{Dr}$ 